\title{
O pensamento de Paulo Freire: gênese e consolidação da educação popular no Brasil
}

\author{
Paulo Freire's thought: genesis and consolidation of popular education in Brazil \\ El pensamiento de Paulo Freire: génesis y consolidación de la educación popular en Brasil
}

Recebido: 13/11/2021 | Revisado: 19/11/2021 | Aceito: 19/11/2021 | Publicado: 29/11/2021

\author{
Ândrea Francine Batista \\ ORCID: https://orcid.org/0000-0001-8841-8089 \\ Universidade Federal do Paraná, Brasil \\ andreafran2008@gmail.com \\ Maurício Fagundes \\ ORCID: https://orcid.org/0000-0003-3623-2973 \\ Universidade Federal do Paraná, Brasil \\ E-mail: mauriciovitoriafagundes@gmail.com
}

\begin{abstract}
Resumo
O presente artigo tem por objetivo analisar aspectos que possam contribuir para um inventário das experiências de Educação Popular, a partir do pensamento de Paulo Freire, no contexto histórico, político e econômico dos últimos anos, com uma maior ênfase a partir do processo de redemocratização até a atualidade. Diante da negação da ciência e de uma educação que possa realizar a crítica dos acontecimentos da atual realidade, não se pode prescindir dos fundamentos do pensamento freireano, que defende uma educação crítica e popular como elemento de emancipação humana. Este estudo desenvolve-se a partir de uma pesquisa bibliográfica de natureza qualitativa, tendo na dialética o método que fundamenta suas análises. Como resultados recupera-se os fundamentos do pensamento freireano por meio de suas principais experiências e de sua articulação com as lutas populares deste tempo. O processo de ação e reflexão de Freire projeta inéditos viáveis, que inspiram novos fazeres e novos compromissos para todos educadores e educadoras, pois não podemos trespassar a vida planetária sem uma práxis transformadoras, pelo risco de incorrermos em uma postura coadjuvante dos rumos nefastos que a crise capitalista, em suas dimensões econômica, social, política, cultural, ambiental e educacional estão configurando.
\end{abstract}

Palavras-chave: Pensamento de Paulo Freire; Educação popular; Lutas democráticas; Emancipação; Educação popular no contexto neoliberal.

\begin{abstract}
The present article aims at analyzing aspects that can contribute to an inventory of Popular Education experiences, based on Paulo Freire's thought, in the historical, political, and economic context of the last years, with more emphasis on the process of re-democratization up to the present time. In the face of the denial of science and of an education that can criticize the events of the current reality, we cannot do without the foundations of Freire's thought, which defend a critical and popular education as an element of human emancipation. This study is developed from a bibliographical research of a qualitative nature, having in the dialectic the method which is the basis of its analysis. As a result, the foundations of Freire's thought are recovered through his main experiences and his articulation with the popular struggles of this time. Freire's process of action and reflection projects viable novelties that inspire new actions and new commitments for all educators, because we cannot go through planetary life without a transforming praxis, at the risk of incurring in a posture of supporting the disastrous directions that the capitalist crisis, in its economic, social, political, cultural, environmental and educational dimensions, is shaping.
\end{abstract}

Keywords: Paulo Freire's thought; Popular education; Democratic struggles; Emancipation; Popular education in the neoliberal context.

\section{Resumen}

El presente artículo pretende analizar aspectos que puedan contribuir a un inventario de las experiencias de Educación Popular, basadas en el pensamiento de Paulo Freire, en el contexto histórico, político y económico de los últimos años, con mayor énfasis en el proceso de redemocratización hasta la actualidad. Frente a la negación de la ciencia y de una educación que pueda criticar los acontecimientos de la realidad actual, es imposible desconocer los fundamentos del pensamiento de Freire, que defienden una educación crítica y popular como elemento de emancipación humana. Este estudio se desarrolla a partir de una investigación bibliográfica de carácter cualitativo, teniendo en la dialéctica el método que fundamenta su análisis. Como resultado, se recuperan los fundamentos del pensamiento de Freire a través de sus principales experiencias y su articulación con las luchas populares de esta época. El proceso de acción y reflexión de Freire proyecta novedades viables, que inspiran nuevas acciones y nuevos compromisos para todos los educadores, porque no podemos transitar por la vida planetaria sin una praxis transformadora, a riesgo de incurrir en 
una postura de apoyo a los desastrosos rumbos que la crisis capitalista, en sus dimensiones económica, social, política, cultural, ambiental y educativa está configurando.

Palabras clave: Pensamiento de Paulo Freire; Educación popular; Luchas democráticas; Emancipación; Educación popular en el contexto neoliberal.

\section{Introdução}

“Chega de doutrinação marxista. Basta de Paulo Freire!”. A faixa de fundo amarelo com "letras garrafais" anunciava uma agenda entre as mobilizações que ocorreram no Brasil em 2015. Esta, no campo da educação, expressava uma síntese da movimentação iniciada em combate à política governamental do Partido dos Trabalhadores. Mas o que essa incômoda faixa poderia nos indicar? Que o sistema de educação brasileira é fundamentado em Freire? Que nas escolas e universidades se estuda incansavelmente o pensamento de Karl Marx?

Sustentam essa agenda movimentos recém-nascidos, que junto à pauta anticorrupção propõe: a legalização do ensino doméstico, nominado por seus postulantes de "homeschooling"; as escolas cívico-militares; a gestão privada de escolas públicas; e o fim da doutrinação ideológica em escolas e universidades. Paralelamente, manchetes destacam polêmicas em torno do pensamento pedagógico de Freire e do suposto aparelhamento nas escolas em benefício de uma esquerda totalitária. Sob essa perspectiva, os problemas da educação brasileira vinham do incansável doutrinamento marxista nas escolas e universidades e da aplicação fiel do método Freireano na educação pública.

Podemos afirmar de antemão que esse pensamento é inconsistente. Para compreender as turvas críticas destes grupos conservadores e neoliberais, bem como a assunção desse discurso por parte de muitos, é necessário um mergulho profundo na formação social brasileira bem como na trajetória da Educação Popular desenvolvida nos últimos anos, que é em síntese tema desta vociferação. Uma educação que se fundamenta numa perspectiva crítica, conscientizadora das classes oprimidas, e, que na verdade nunca foi hegemônica na história de nosso país.

Este artigo tem por objetivo analisar aspectos que possam contribuir para um inventário das experiências de Educação Popular, a partir do pensamento de Paulo Freire, no contexto histórico, político e econômico dos últimos anos, com uma maior ênfase a partir do processo de redemocratização até a atualidade, como possibilidade de compreender os elementos que sustentam tal pensamento. Identificar o que foi realizado e que mediações foram condicionantes nestas experiências podem dar melhor visibilidade e instrumentos frente aos desafios desse tempo histórico.

Este artigo busca destacar elementos importantes para um balanço das experiências de Educação Popular desde o processo de redemocratização até a atualidade a partir das premissas e fundamentos do pensamento de Paulo Freire. Sob o alento do materialismo dialético como método, os elementos aqui apresentados têm origem numa pesquisa essencialmente bibliográfica e de natureza qualitativa, que se apoiou no materialismo dialético para compor suas análises. O texto principia com a contextualização educação popular e as tensões democráticas no Brasil, seguido a este apresenta-se o legado da educação popular na América Latina e seus movimentos pelo mundo; retornando ao Brasil, apresenta-se o legado da educação popular reveladas nas teses e dissertações brasileiras, compreendidas no período de 1986, que marca o final da ditadura militar e início do período de redemocratização, até o ano de 2019. Segue-se a este os fundamentos do pensamento de Freire na trajetória da Educação Popular, concluindo com as considerações finais.

\section{Metodologia}

A metodologia que deu corpo a este artigo fundamenta-se em um ensaio teórico de natureza qualitativa. A investigação qualitativa é definida por Bogdan e Biklen (1994) por cinco características, das quais, podem ou não aparecerem em sua totalidade, de modo que não descaracteriza sua natureza qualitativa. No caso deste estudo, o situamos em quatro dessas características, as quais passamos a sinalizar: a investigação qualitativa é descritiva; os investigadores qualitativos interessam- 
se mais pelo processo do que simplesmente pelos resultados ou produtos; os investigadores tendem a analisar os seus dados de forma indutiva; e, por último, o significado é de importância vital na abordagem qualitativa.

A abordagem realizada foi por meio de um estudo de caso numa perspectiva histórica reflexiva, que é definido por Bogdan e Biklen (1994, p. 90) como: "estudos que incidem sobre uma organização específica, ao longo de um período determinado de tempo, relatando o seu desenvolvimento". Neste estudo o caso em estudo é a consolidação da educação popular como reflexo do pensamento e obra de Paulo Freire.

A coleta dos dados se deu por meio de um levantamento bibliográfico e análise documental. Foram utilizados fontes como: a obra de Paulo Freire e de autores que produziram sobre a educação popular; produções publicizadas em websites acerca da importância da obra e de autores que a criticam; e dos dados do Banco de Teses e Dissertações da CAPES, no marco temporal do ano de 1986, que marca o final da ditadura militar e início do período de redemocratização, até o ano de 2019.

Os documentos, segundo Lüdke e André (1986, p. 39) “constituem também uma fonte poderosa de onde podem ser retiradas evidências que fundamentem afirmações e declarações do pesquisador. Representam ainda uma fonte 'natural' de informação. Não são apenas uma fonte de informações contextualizada, mas surgem num determinado contexto e fornecem informações sobre esse mesmo contexto".

O estudo resgata o processo histórico, os fundamentos, as experiências da educação popular na América Latina e no Brasil e o seu legado, por meio do levantamento das fontes, acima mencionadas, em diálogo com as produções bibliográficas de vários estudiosos da área. A partir dessa sistematização passou-se a analisar os fundamentos da obra de Paulo Freire na trajetória da Educação Popular.

A análise de conteúdo seguiu os preceitos de Bardin (2016) organizando os dados por meio das três etapas: préanálise, descrição analítica e interpretação inferencial, assumindo como aporte epistemológico para a análise o materialismo histórico dialético (Marx \& Engels, 2001).

\section{A Educação Popular e as Tensões Democráticas no Brasil}

O pensamento de uma época, mesmo com todas suas variantes, contradições e embates, carrega uma linha tênue que demarca toda sua diversidade, uma efêmera margem que de maneira imperceptível baliza aspectos de um tempo histórico. A Educação Popular nasce num marco como esse, e como tudo que é vivo, vai se transformando e consolidando-se na concretude de seu fazimento. Se há distanciamentos entre seus princípios, formulações e a experiências? Com certeza. Até porque a relação entre uma projeção e sua materialidade carrega uma infinidade de mediações. Contudo, mesmo nessa atrição e seus desdobramentos, ainda sim, fazem parte desse tempo histórico. Na sequência traçamos aspectos importantes para um inventário da educação popular nesse tempo.

Antes disso, é fundamental esboçar algumas palavras sobre o que entendemos por inventário. Para além de levantar dados ou realizações, é um processo que busca analisar as singularidades entre as particularidades de cada ação. O caminho no encontro dessas singularidades pode captar elementos do pensamento de uma época, da consciência social de uma época. Necessita também do estudo das contradições e mediações que movimentaram a experiência concreta e seus processos análogos. Exige método, e aqui destacamos a importância do materialismo dialético que nos instiga a desconstruir leituras mecanicistas e lineares que muitas vezes assolam de maneira inconsciente nossa atitude investigativa. É sensato apontar aqui, que as linhas que seguem não pretendem ser uma sistematização profunda, mas uma singela contribuição a esse longo, amplo e coletivo processo - o de inventariar a Educação Popular no Brasil. Assim apresentamos esse artigo.

Muito embora no início do século XX houveram experiências importantes de educação para transformação social, como as do movimento anarco-sindicalista na construção de "escolas livres" e centros de cultura, a educação popular nasce no Brasil, originariamente, junto à igreja católica e movimentos sociais, como: Movimento de Educação de Base - MEB, as 
escolas radiofônicas no Nordeste, e o Movimento de Cultura Popular - MCP, respectivamente (Fávero, 1983). Porém, foi desde o nordeste brasileiro por meio das experiências de Paulo Freire com alfabetização de jovens e adultos realizada em Angicos (RN) e Pernambuco em 1963, que a educação popular ganhou o mundo. Articulando a alfabetização ao processo de conscientização das classes oprimidas - a leitura da palavra e do mundo buscava abrir caminhos para que a classe trabalhadora pudesse construir sua própria história, muito embora encharcada de condicionantes como afirmará posteriormente em um de seus livros, a Pedagogia da autonomia (Freire, 1996).

O êxito da experiência de Angicos levou o então presidente João Goulart a institucionalizar o método de alfabetização usado por Freire em janeiro de 1964 (Plano Nacional de Alfabetização - PNA). Um programa que previa a criação de 60 mil círculos de cultura para alfabetização. O governo de Jango, Partido Trabalhista Brasileiro', anunciaria alguns meses mais tarde um programa de "reformas de base", entre as quais, a reforma agrária. Jango havia assumido inicialmente a presidência a partir da renúncia de Jânio Quadros (1961) numa situação de instabilidade política.

Mas, em março de 1964, um discurso proferido por Jango na Central do Brasil (RJ) seria o estopim do golpe civilmilitar realizado em 01 de abril deste mesmo ano ${ }^{2}$. Cerca de 200 mil pessoas acompanharam o ato político que anunciava a Reforma Agrária, extremamente combatida por latifundiários e parlamentares.

A ditadura civil-militar extinguia o PNA substituindo-o pelo Movimento Brasileiro de Alfabetização (MOBRAL), encarcerava e exilava Paulo Freire, repreendia os Centros Populares de Cultura (CPC), o Movimento Eclesial de Base, a Confederação Nacional dos Bispos do Brasil (CNBB), fechava o Congresso Nacional e extinguia partidos políticos colocando muito deles na clandestinidade.

Entre as forças políticas que lutavam pela transformação societária na década de 1960 é importante destacar o Partido Comunista Brasileiro, as Ligas Camponesas, as lutas posseiras e sindicais, entre outras. A intensa repressão, especialmente após o AI5, fez com que surgissem muitas organizações de caráter clandestino, como a Aliança Nacional Libertadora (ALN) e a Vanguarda Popular Revolucionária (VPR). No campo cultural, o cinema novo (1950-1960) e o teatro do oprimido (1970) destacavam a articulação entre a arte e conscientização. Os festivais da música popular brasileira tornaram-se espaço de visibilidade das canções de protesto, ao passo que "cantautores" driblavam a censura a partir de metáforas. Repressão e censura também no âmbito da comunicação e do movimento estudantil. Não foram poucos os que se agrupavam junto às Comunidades Eclesiais de Base para fazer o possível trabalho de conscientização e organização.

Nesse contexto, Freire em seu exílio ${ }^{3}$ produziu belas obras retratando sua concepção de educação popular ${ }^{4}$. Necessariamente estreita às causas e lutas populares por direitos, Freire estudou a fundo a educação destacando sua responsabilidade conscientizadora e suas dimensões para além do espaço escolar e da escolarização. Essa visão ampla de processos educativos societários, davam visibilidade ao "quefazer educativo" existente na vida cotidiana, na comunicação popular, no papel do "agrônomo orientador", na religiosidade (sob perspectiva da teologia da libertação), no trabalho social, na participação comunitária, na luta pela libertação e na organização popular.

A ditadura, segundo Freire (1967), interrompia o curso de uma transição societária que abria a possibilidade da superação de uma época de acomodação, ajustamento, alienação cultural, uma época antidemocrática. Um período que rompia com a coisificação do ser humano possibilitando a "descoberta de sua temporalidade" e a consciência de sua "historicidade". Nesse tempo do trânsito latente, a sociedade brasileira estava à procura de novos temas, novas tarefas. E nesse sentido, o papel

${ }^{1}$ PTB. Partido fundado em 1945 por Getúlio Vargas onde atuou também Leonel Brizola. Extinto pela ditadura de 1964, na abertura política se dividiu em PDT (1979) е РTB (1981).

${ }^{2}$ O documentário de Flávio Tavares, "O dia que durou 21 anos" demonstra o papel dos EUA na intervenção militar no Brasil e seu vínculo com interesses empresariais.

${ }^{3}$ Chile (1964-1969);EUA (1969-1970); Genebra (1970-1980).

${ }^{4}$ Educação como prática da Liberdade (1967); Pedagogia do Oprimido (1968); Extensão e Comunicação (1968); Ação Cultural para a Liberdade e outros escritos (1978); entre outras. 
do educador imbuído desse dinamismo era o de anunciar e distinguir de maneira lúcida os embates entre o velho e o novo. A crescente "emersão popular" indicava a chave desse trânsito, porém, o Golpe de Estado impunha violentamente um recuo "catastrófico", e a partir de uma postura sectária, reacionária e antidialogal, retardava o processo em curso.

Mas Freire $(1967 ; 1985 ; 1987)$ também destacava o incômodo quando essas posturas assolavam as próprias organizações e movimentações que impulsionavam tal trânsito. Afirmava que a postura radical na construção de uma revolução verdadeiramente libertadora deveria ser imbuída de ação-reflexiva, de dialogicidade, de colaboração, síntese cultural, unidade e organização, onde os sujeitos, "com outros sujeitos" poderiam "acelerar as transformações”. Nesse sentido, é indiscutível o vínculo de Freire com as lutas democráticas de seu tempo.

Em termos gerais, a ditadura civil-militar provocou em muitos pensadores brasileiros a necessidade de compreender mais a fundo esse processo. Nessa perspectiva: Caio Prado Junior escreve em 1966 "A Revolução Brasileira"; Florestan Fernandes em 1969 “A Revolução Burguesa no Brasil”; Vânia Bambirra em 1969 escreve "Imperialismo e Dependência”; Rui Mauro Marini em 1973 "Dialética da Dependência", entre tantos outros. Temas como sub-imperialismo, capitalismo dependente, papel autocrático e intransigente da burguesia nacional, teoria e programa da revolução brasileira, e, democracia, foram decisivos na análise. Esses temas iriam influenciar enormemente nas formulações estratégicas que viriam tomar corpo no final da década de 1980 e consolidar-se nas décadas seguintes com a formação do campo democrático-popular.

A década de 1980 no Brasil foi marcada por uma profunda crise econômica onde o projeto econômico desenvolvimentista que havia promovido uma certa constância de crescimento do PIB desde a década de 1940 desacelerou, abrindo margens para a implantação de políticas neoliberais a partir da década de 1990. O Fundo Monetário Internacional (FMI) e Organização Mundial do Comércio (OMC) iriam nos próximos anos ser responsáveis por impulsionar um conjunto de acordos multilaterais promovendo a redução tarifária no comercio internacional.

No campo político, a agitação nas ruas e a impossibilidade de manter o regime ditatorial impulsionou sua "lenta e gradativa" transição. Inúmeras organizações sociais populares nasceram e/ou retomaram suas atividades políticas após longos 20 anos de intensa repressão, onde poucos foram os espaços ${ }^{5}$ em que os setores populares conseguiram se agrupar para uma atuação política.

A greves operárias na região do ABC paulista (1978-1980) protestavam contra o arrocho salarial, empunhando a bandeira da liberdade e autonomia sindical. A lei da anistia (agosto de 1979) ampla e irrestrita possibilitava o retorno de exilados políticos ao Brasil, inclusive de Paulo Freire (junho de 1980). Nesta década também ocorre o nascimento do Partido dos Trabalhadores (1980) e da Central Única dos Trabalhadores (1983); as manifestações das "Diretas Já" (1983-1984); a promulgação da Constituição Brasileira (1988) e a eleição direta para presidência da república (1989).

Em termos de projetos políticos, nesse período foram gestados debates que se evidenciaram na campanha presidencial de 1989. Um dirigente metalúrgico de nome Luís Inácio (Lula) é candidato pelo já consolidado Partido dos Trabalhadores (PT) empunhando um programa democrático-popular, e por outro lado, a classe dominante brasileira com um programa neoliberal, que vencedor, promoveu a privatização de empresas estatais como a Embratel (telecomunicações), e políticas de comércio exterior que impulsionariam o então agronegócio.

Na década de 1980, ao retornar ao Brasil, Freire lecionou em universidades e assumiu a Secretaria de Educação do Município de São Paulo durante a gestão de Luíza Erundina (PT). Suas obras nestas duas décadas retomavam a conscientização e o papel da educação nas mudanças sociais, bem como os desafios da educação popular no espaço da escola pública ${ }^{6}$.

\footnotetext{
${ }^{5}$ Como as Pastorais Operárias e as Comunidades Eclesiais de Base (CEBs) desenvolvendo ações compromissadas com as causas populares sob as bases da Teologia da Libertação.

${ }^{6}$ Como por exemplo, o artigo "Construindo a Educação Pública Popular” (1989), e o caderno "S.M.E. Construindo a Educação Pública Popular. Diretrizes e Prioridades para 1991” (Fevereiro de 1991).
} 
A educação popular materializava-se de maneira diversa. Pontualmente em espaços da educação pública, e muito mais incidente e diversa junto às iniciativas comunitárias de alfabetização, aos movimentos sociais populares, na criação de escolas sindicais e centros de formação, como por exemplo: Centro de Educação Popular do Instituto Sedes Sapientiae (CEPIS), Centro de Formação Urbano Rural Irmã Araújo (CEFURIA), o 13 de Maio Núcleo de Educação Popular (NEP), e a Escola Nacional Florestan Fernandes (ENFF-MST).

Em 2002 Lula foi eleito presidente. O Partido dos Trabalhadores assumia os próximos quatro mandatos sob um programa já transformado de sua origem, e de fundo neodesenvolvimentista ${ }^{7}$. Muitos programas sociais possibilitaram melhorias nas condições de vida da classe trabalhadora, retiraram um número expressivo de pessoas da linha da pobreza, possibilitaram a expansão e interiorização do ensino superior. Mas, ao mesmo tempo impulsionaram o crescimento de empresas nacionais ou de capital majoritariamente brasileiro, especialmente as produtoras de comodities agrícolas, impactando diretamente na vida de camponeses, indígenas quilombolas e comunidades tradicionais. $\mathrm{O}$ engodo, é que a crise capitalista mundial iria interferir de maneira indigesta em tal política econômica.

Entre os anos de 2013 e 2016 muitas mobilizações efervesceram nas ruas culminando no impeachment da presidenta Dilma Roussef (PT). As distintas posições políticas se acirravam. Por um lado, organizações de caráter conservador e/ou liberal esbravejavam contra o partido e seu governo como o Movimento Brasil Livre (MBL), Movimento "Vem para a Rua", "Movimento Escola sem Partido". E, por outro, partidos e movimentos populares progressistas fazendo a crítica às consequências de sua política neodesenvolvimentista, mas anunciando o curso de um golpe de estado de novo tipo no país. Ocupação das escolas faziam o embate contra corte de recursos para educação, contra a sua privatização e o fechamento de escolas públicas.

Nesse cenário, vocifera-se contra o pensamento de Paulo Freire, afirmando que sua pedagogia levava à doutrinação política, ideológica9 e partidária. Que para ele, o professor deveria ser um "doutrinador" partidário, instigando estudantes a se tornar militantes, e que em sua concepção o ensino de "conteúdos programados e disciplinares" seria parte de uma alienação. Nessa linha de raciocínio, a consciência crítica seria "nada menos que manipulação política e ideológica" e "propaganda" do "pensamento marxista" (Azevedo, 2019) ${ }^{10}$.

Sem adentrar nos meandros dessas inconsistentes argumentações, no limite essa postura é bastante coerente com seu projeto societário. Aquele que, calcado na formação de um capitalismo dependente segue produzindo prioritariamente para exportação, e, subsumido ao imperialismo produz burguesias nacionais autocráticas e extremamente intransigentes sob qualquer risco aos seus privilégios, até mesmo no reconhecimento dos direitos básicos à classe que a sustenta (Fernandes, 1976).

\section{O Legado das Experiências de Educação Popular}

Como temos apresentado até aqui, as experiências de educação popular são inúmeras e abrangem um território geográfico que não respeitam fronteiras físicas, pois são demarcadas pelo compromisso social e político na direção de um horizonte de superação das condições dos povos oprimidos, que Paulo Freire chamou de inéditos viáveis. Por essa razão, são experiências que, principalmente, a partir da década de 1960, passaram a se multiplicar no mundo, mas em especial na América Latina.

\footnotetext{
${ }^{7}$ Ver: KATZ, Cláudio. Neoliberalismo, neodesenvolvimentismo, socialismo. SP. Expressão Popular, 2016.

${ }^{8}$ Criado em 2004 pelo advogado Miguel Nagib, primeiro como projeto e depois como movimento, atua no combate à "ideologia de gênero" e o aparelhamento de escolas/universidades difusoras da propaganda partidária e da esquerda. Nagib deixa oficialmente o movimento em agosto de 2020 justificando sua atual desvalorização.

${ }^{9}$ Sobre o tema da ideologia, nos apresenta um panorama crítico a obra de KONDER, Leandro. A Questão da Ideologia. SP: Companhia das Letras, 2002.

${ }^{10}$ Azevedo, Jonas da Silva. Porque o pensamento de Paulo Freire leva à doutrinação ideológica, política e partidária? Escola Sem Partido. On-line: Escola Sem Partido, 5 de julho de 2019.
} 
Com essa compreensão histórica de conhecimento, principiaremos destacando a origem histórica e a perspectiva política da educação popular, bem como os seus principais pensadores na América Latina. Para traçar esse panorama nos apoiamos, principalmente, na obra de Oscar Jara (2020) “A educação popular latino-americana: história e fundamentos éticos, políticos e pedagógicos". Nessa obra o autor retoma os antecedentes da educação popular, a partir do século XVIII, momento em que a América conduzia seus processos de independência frente ao colonizador espanhol e português. Após essa retomada histórica, apresentamos as produções acadêmicas de dissertações e teses brasileiras, sobre o legado freireano acerca da educação popular, a partir do ano de 1986, que demarca o final da ditadura militar e início do período de redemocratização, até o ano de 2019.

\subsection{O legado da educação popular na América Latina e seus movimentos pelo mundo}

Avançando para os nossos dias, finais do século XX e início do século XXI, passamos a destacar alguns movimentos e publicações que tem reinventado essa proposta que teve início no século XVIII. O marco contemporâneo desse processo se deu por meio de Paulo Freire com a obra Pedagogia do Oprimido onde o autor fez a denúncia das relações de opressor e oprimidos, da educação bancária e os caminhos para a construção de um processo libertador por meio dialogicidade.

As publicações e movimentos dos anos 1970 ao final do século XX avançaram e recuaram na América Latina tensionados pelos golpes militares. A exemplo disso podemos citar os Cuadernos de Educación popular, que foi publicado até o ano de 1973, no Chile, momento em que o golpe militar interrompeu as publicações.

Porém, nesse período, na Nicarágua, a história mostra que movimentos em direção a libertação são possíveis, pois em 1979 aconteceu o triunfo da Insurreição popular contra a ditadura de Somoza e a constituição do Grupo Regional de Apoio à Educação Popular.

Na perspectiva emancipatória, no ano de 1977, Paulo Freire publicou Cartas a Guiné Bissau. Livro que reúne cartas escritas por Paulo Freire ao Comissariado de Educação e à Comissão Coordenadora dos trabalhos de alfabetização em GuinéBissau, quando com a equipe do IDAC (Instituto de Ação Cultural) e do Conselho Mundial de Igrejas assessorou aquele país no seu processo de reconstrução após a independência de Portugal (Souza, 2010).

Em 1979, no Brasil, a ditadura militar enfraquecida, sinalizava a abertura política e o retorno dos brasileiros exilados. Nesse momento, em que Freire se preparava para voltar do exílio, publicou Educação e mudança, onde destacava o necessário compromisso do profissional para com a sociedade.

No ano de 1982 foi criado o Conselho de Educação de Adultos da América Latina - CEAAL, sendo Paulo Freire seu primeiro presidente. Nesse mesmo ano de 1982, em Bogotá, Colômbia, foi lançada a Revista APORTES, que publicou até o ano de 1996, temas de perspectiva libertadora. Nesse mesmo ano de 1982, Paulo Freire, publicou o livro A importância do ato de ler.

No ano de 1984 foi criada a Rede Latino-americana e Caribenha de Educação Popular - Religiosas do S. Cobrazona, Bogotá, por educadoras e sua opção pelos pobres. Nesse mesmo ano de 1984, destaca-se a constituição da Red de Educación Popular de Mujeres de América Latina y Caribe (REPEM), para fortalecer o movimento popular de mulheres por meio da ação educativa (Jara, 2020).

No ano de 1991, Paulo Freire publicou o livro A educação na cidade. Neste livro reflete a experiência como educador e gestor, Secretário Municipal de Educação, ao sistematizar sua passagem como Secretário de Educação da cidade de São Paulo na gestão de Luiza Erundina.

O ano de 1992 foi marcado pela realização da Conferência Mundial sobre Meio Ambiente e Desenvolvimento - ECO 92, no Rio de Janeiro. Nesse mesmo ano, Paulo Freire, lançou o livro Pedagogia da Esperança: um reencontro com a Pedagogia do Oprimido. 
No ano de 1993 foi realizada em Viena, Áustria, a Conferência Mundial sobre os Direitos Humanos. Nesse mesmo ano Paulo Freira publicou o livro Política e educação. Esse livro tem como fio condutor a reflexão político-pedagógica emancipatória.

Também no ano de 1993, Paulo Freire, publicou outra obra: Professora sim, tia não: cartas a quem ousa ensinar. Paulo Freire discute, nesse livro, o autor afirma que é preciso gritar alto que, ao lado de sua atuação no sindicato, a formação científica das professoras iluminada por sua clareza política, sua capacidade, seu gosto de saber mais, sua curiosidade sempre desperta, são os melhores instrumentos políticos na defesa de seus interesses e de seus direitos (Souza, 2010).

No ano de 1994 foi realizada a III Assembleia CEAAL em Havana, com o tema refundamento da Educação Popular. No México acontecia o levante Zapatista, em Chiapas. O levante durou 12 dias e teve repercussão internacional, devido às suas demandas por justiça e defesa dos direitos dos povos indígenas e dos pobres do México. Até hoje é uma das mais importantes organizações de camponeses do mundo e um exemplo de luta e resistência popular contra a pobreza e a desigualdade social. No Brasil, nesse ano de 1994, Paulo Freire publicou a obra Cartas a Cristina. No livro, Freire aborda lembranças da infância, da formação pessoal e acadêmica e de sua militância política.

No ano de 1995, foi realizada em Copenhague, Dinamarca, a Cúpula Mundial sobre Desenvolvimento social e, no mesmo ano na China, em Beijing, a Conferência Mundial de Mulheres. No Brasil, Paulo Freire, publicou a obra intitulada $\grave{A}$ sombra desta mangueira. Nesta obra, o autor reafirma sua radicalidade absoluta a favor dos oprimidos, recusando o mecanicismo e determinismo que gera o imobilismo; reafirma, sobretudo, a história como tempo de possibilidade, a esperança, a tolerância, a dialogicidade e a problematização, como exigências ontológicas dos seres humanos (Souza, 2010).

Em 1996, Paulo Freire publicou sua última obra em vida, a Pedagogia da autonomia. Nela o autor articula: historicidade, politicidade, dialogicidade, eticidade, problematização, amorosidade e esperança, entre muitas outras categorias fundamentais à construção da própria autonomia do trabalho docente e dos educandos e educandas (Souza, 2010).

Nos anos que se seguem de 1996 até o ano de 2001, foram marcados pela intensificação da educação popular, mobilizando comunidades e associações em toda a América Latina, com movimentos de resistência e articulações para a construção de um novo projeto de sociedade, para fazer frente às propostas neoliberais. Nesse ano de 2001, esses movimentos e propostas que aconteciam nos vários países, se concentram e inauguram o I Fórum Social Mundial, realizado em Porto Alegre, reunindo cerca de 15.000 pessoas vindas dos mais distintos lugares. A mobilização que movimentou a construção do I Fórum Social Mundial, tinha como objetivo mostrar ao mundo de que um outro mundo é possível, muito bem sintetizado nesse slogan. A mobilização e as temáticas ali discutidas de um outro projeto societário, tinha endereço, precisava dizer ao mundo e a cúpula dos países ricos, reunidos, naquele mesmo momento, no Fórum Econômico Mundial, em Davos, na Suíça, que outro mundo é possivel!

Nos anos que seguem de 2002 a 2018, o Fórum passou a reunir em cada evento, mais de 100 mil pessoas e se deslocou de Porto Alegre para outros países de terceiro mundo, pois havia o entendimento da importância de fazer circular essa proposta e contemplar outros países, como: a Índia em 2004; Nairóbi, Quênia em 2007; no ano de 2010 decidiu-se pela descentralização, acontecendo em 27 países, simultaneamente; em Dakar, Senegal no ano de 2011; no continente Africano, na Tunísia em 2013; na Tunísia em 2015; e nos anos de 2016 e 2018 voltam a ser sediados em Porto Alegre e nesse intervalo do ano de 2017 foi realizado em Montreal no Canadá. Nos intervalos entre as saídas para o exterior, o Fórum retornava e acontecia em Porto Alegre - RS.

Durante esse período dos Fóruns Mundiais, em diversos países se intensificava a discussão da educação popular e da obra de Paulo Freire, como por exemplo: Fóruns de estudos e leituras de Paulo Freire (Rio Grande do Sul - Brasil); Seminários Paulo Freire, Recife, Pernambuco; Encontros Latino-americano e caribenho de Educação popular; Seminários Latinoamericano de educação popular, Córdoba - Argentina; Encontros internacionais do Foro Paulo Freire, Instituto Paulo Freire - 
São Paulo - Brasil; Encontro Internacional de Educação alternativa e especial e Encontro da Região Andina do CEAAL, em La Paz, Bolívia; Assembleias de Educação Popular do CEAAL em San Salvador - El Salvador; Lima - Peru; Quito, Equador; Guadalajara, México e Buenos Aires, Argentina (JARA, 2020).

\subsection{O legado da educação popular revelada nas produções de dissertações e teses}

Como já anunciado, apresentamos neste item o legado freireano da educação popular, registrada nas produções das dissertações e teses desenvolvidas nas universidades brasileiras, no marco temporal do ano de 1986, que marca o final da ditadura militar e início do período de redemocratização, até o ano de 2019. Como principal fonte de busca, elegemos o Banco de Teses e Dissertações da CAPES, por entender que concentra as sistematizações das pesquisas desenvolvidas em todo território brasileiro, no que diz respeito a pós-graduação.

Inicialmente, fizemos uma busca com o descritor educação popular. Para esse descritor constatou-se um total de 1.749 produções, sendo 1.337 dissertações e 412 teses. Refinando a pesquisa, utilizamos como descritores: educação popular AND redemocratização OR lutas sociais. O número de total de produções entre teses e dissertações somou 174, sendo 144 dissertações e 30 teses.

Foi possível constatar que a temática educação popular produziu teses e dissertações em 17 estados brasileiros. O maior número de produções ficou concentrado nos estados da: Paraíba, com 24 dissertações e 5 teses; Rio Grande do Sul, também com 24 dissertações e 6 teses; São Paulo, com 20 dissertações e 8 teses; Rio de Janeiro, com 16 dissertações e 3 teses; Mato Grosso com 16 dissertações; Ceará com 11 dissertações e 4 teses; Rio Grande do Norte e Minas Gerais 6 dissertações cada um; Paraná, 4 dissertações; Santa Catarina, 3 dissertações e uma tese; Bahia, 3 dissertações e 1 tese; Amazonas, Goiás, Brasília e Pará, 2 dissertações, sendo que o Pará apresentou também 1 tese; Espírito Santo 1 dissertação e Piauí 1 tese.

As temáticas em sua maioria discutiam a educação popular na relação com os movimentos sociais e com escolas na perspectiva da transformação social. Pode-se constatar que as produções, a partir do ano de 1987 até o ano de 2005, mantiveram uma média de em torno de 4 produções por ano. Essa média dobra nos últimos 13 anos, passando em torno de 8 produções ao ano.

A avaliação da quantidade de produções, se tomada como referência apenas o descritor "educação popular", que evidenciou 1.749 produções e se fossemos fazer uma média, dividindo-as pelos 33 anos pesquisados, teríamos uma média de 53 produções por ano, o que significa a assunção da educação popular como aporte prático-teórico por um grande número de pesquisadores.

Essas produções sobre o pensamento freireano, aportado na educação popular, nos demonstram o rigor da presença de Paulo Freire na imensa maioria dos estados brasileiros. Mais do que se fazer presença, evidencia o significado dentro das pesquisas científicas desenvolvidas pela academia brasileira, demarcando posições políticas na busca de caminhos pautados em uma perspectiva dialética e dialógica para a formação de seus intelectuais. Apresentado este cenário quantitativo e qualitativo, passaremos a apresentar os fundamentos do pensamento de Freire implícitos na educação popular.

\section{Fundamentos do Pensamento de Freire na trajetória da Educação Popular}

A Educação Popular nasce no âmago dos processos sociais de transformação. Esse seu vínculo é umbilical e constitui um de seus aspectos fundantes. É também seu combustível e retroalimenta a larga trajetória do encontro dos seres sociais com sua emancipação. Uma real transformação, para além das mudanças econômicas e políticas, exige também conscientização, ação-reflexiva e reflexão-ativa nas várias dimensões da vida humana.

A tensão existente nesse elo alienação-conscientização exige um trabalho rigorosamente metódico, de constância, perseverança e afinco. É um tema que vem partejar a educação popular, e por assim dizer é extremamente doloroso. E, ao 
contrário do que esbravejam os conservadores, a conscientização não se define por instaurar uma determinada ideologia "esquerdista e totalitária", mas em possibilitar uma leitura crítica da sociedade e do próprio sujeito histórico desobstruindo a névoa que o entorpece. Conscientização na acepção de Freire representa o encontro compromissado e amoroso do ser humano com sua existência, com sua temporalidade, impulsionando-o para uma esfera além da "órbita vegetativa" e da acomodação. Possibilita o reconhecimento da opressão e dos condicionamentos que fazem a existência humana massificada, acrítica e coisificada. Sua superação envolve assunção da construção da própria história. Sua superação decorre em sua própria humanização.

Essa "transição", para o autor se desenvolve "[...] dentro de certas condições em que homem seja lançado ao debate, ao exame de seus problemas e dos problemas comuns. Em que o homem participe" (Freire, 1967, p. 82). A democracia assim, "antes de ser forma política" é uma "forma de vida" que caracteriza a movimentação da consciência. Portanto, democracia e participação popular são consanguíneos. A participação orgânica dos oprimidos na vida comunitária, nos conselhos, nos bairros, na igreja, associações e agremiações, seria então a democracia viva que em sua própria dinâmica poderia levar a superação da ingenuidade, e de uma "consciência intransitiva". Consciência e ação compõem assim uma unidade dialética.

Nesse sentido, a educação tem estreiteza com "responsabilidade social". Mas para isso, além do seu amplo e irrestrito acesso por parte das populações oprimidas, o método necessita também recriar-se. Superar sua desassociação da realidade concreta; inspirar uma atitude investigativa diante do mundo; alçar a dimensão do conhecimento imediato; e, o "reconhecimento e assunção" identitária como parte de um processo de emancipação humana, seriam temas da educação popular.

Nesse sentido, é inegável considerar que Paulo Freire junto a outros pensadores brasileiros contribuíram para as bases das formulações do campo democrático-popular de transformação após longos anos de chumbo. Nessa perspectiva, a participação popular na busca pela consolidação de seus direitos básicos se configura como parte da democratização e ao mesmo tempo objetiva condições para a assunção da história e seu papel criador do futuro, para a própria humanização.

Longe de afirmar que Paulo Freire, como intelectual orgânico das lutas de seu tempo, foi um dos idealizadores da mobilização e organização popular que seguiram. Mas sim, foi um dos que souberam identificar com maior precisão as contradições do período, suas consequências, bem como apontar caminhos de superação.

Nesse caso, a educação libertadora assume uma função essencial na larga trajetória da busca pela emancipação humana. Uma educação que através da persistente dialogicidade na práxis humana por sua libertação, poderia promover avanços significativos. Uma educação presente na organização popular, e nos trabalhos sociais. Uma educação que para além do espaço escolar, o tem como um pilar fundamental, pois articula conhecimentos técnicos e científicos produzidos historicamente pela humanidade e que necessitam ser apreendidos. Uma educação que supere formas mecânicas, lineares e pragmáticas de socialização e produção de conhecimento, que promova um diálogo problematizador entre o conhecimento empírico, realidade concreta e o conhecimento historicamente construído, que dê visibilidade à dinâmica dialética da vida, de sua apreensão e interpretação.

As bandeiras democráticas como terra, trabalho, casa, salário, diversidade, fim da discriminação racial, educação, são alçadas num marco temporal de tensionamentos, onde por um lado emerge a participação popular através de diferentes formas organizativas, e por outro, repressões estruturadas numa classe dominante de trajetória colonialista, coronelista, e subsumida ao imperialismo. Tensões que se evidenciaram tanto na ditadura de 64 como no golpe de 2016. A própria formação social brasileira, em suas dimensões econômica, política e cultural, estiveram marcadas por estes conflitos, e atualmente num marco de distopia, incitação à agressividade, à intolerância e à intransigência às pautas democráticas.

A expressão sob a qual iniciamos essas reflexões nos parece emblemática. Basta de Paulo Freire, poderia significar basta de participação popular? Basta de conscientização? 
Nos parece que essa expressão faz parte um conjunto de sintomas que indicam a gravidade da crise capitalista vivenciada nos últimos tempos. Uma crise, que segundo Mészáros (2011), é estrutural e age na totalidade da sociedade, uma crise permeada pela expansão brutal e devastadora, pela exploração extrema, pela espoliação contínua e destruidora da natureza, pela produção e consumo destrutivos, pela obsolescência programada ${ }^{11}$. Processo que coloca em risco a própria vida planetária.

E, entre tantas divagações a fim de entender essa expressão em seu contexto, é certeira a necessidade de construir análises profundas sobre o marco temporal em que vivemos, bem como dos motivos que uma parte considerável da população assume como seu o projeto político do opressor, mesmo diante desta trajetória de organização e educação popular.

\section{Considerações Finais}

A educação popular em sua trajetória foi tomando um caminho diverso. Algumas experiências fortemente respaldadas no pensamento de Freire, outras em diálogo com seu pensamento, e outras ainda em sua crítica quanto ao método. Todas elas riquíssimas, sejam no âmbito escolar ou de processos educativos não vinculados à escolarização.

O legado do pensamento de Paulo Freire se expressa na práxis das experiências de educação sob a perspectiva libertadora em nível nacional e internacional, como por exemplo: processos de educação de jovens e adultos; criação centros e redes de educação e cultura popular; encontros de educação popular sob a articulação latino-americana e mundial. Também se evidencia na criação de boletins, revistas e periódicos sobre o tema, bem como na produção bibliográfica acadêmica dos últimos anos. Espaços de debate, sistematização, e análise das experiências construídas.

Essas experiências e articulações revelam-se frutos de um processo político amplo que vincula a educação às metamorfoses sociais e do próprio ser humano. Promovem e ressignificam o papel das condições subjetivas nos processos de mudança, a importância da identidade, bem como ação-reflexiva individual e coletiva.

Inegavelmente, Freire tornou-se uma referência na educação popular. Através de sua militância política, demonstra coerência na postura diante da vida, da educação, do conhecimento e da luta com as classes oprimidas. No plano teórico, o diálogo com autores como Erick Fromm, Karl Marx, Frantz Fanon, Álvaro Vieira Pinto, Vladimir Lênin e Ernesto Guevara, destaca fundamentalmente que a pedagogia do oprimido está em sua luta pela humanização, o que exige superação da coisificação e alienação.

Sua contraposição à concepção bancária de educação está no caráter domesticador e subserviente à dominação, nunca no questionamento dos conhecimentos acumulados historicamente. (FREIRE, 1996). A dialogicidade aqui não se caracteriza por desqualificar o papel dos conteúdos escolares, mas em promover o diálogo entre conhecimento empírico, senso comum e os conhecimentos científicos na realidade concreta, pois esta é, em última instância, a base que carrega as contradições, opressões e as possibilidades de mudança. Aliás, a intepretação da realidade concreta está repleta de tensionamentos entre todas essas dimensões.

A singularidade de seu pensamento e das variadas experiências de educação popular fazem parte da práxis social de uma época. Uma época em que democracia e participação popular são intrínsecas, em que a luta política por direitos econômicos, sociais, humanos perpassam necessariamente pelo caminho das lutas democráticas.

Compreender profundamente o legado da educação popular nesse marco pode contribuir para enfrentar os desafios desse tempo histórico e superar contradições em suas nuances.

O desenvolvimento da ordem capitalista de maneira desigual e combinada sob a égide imperialista, apresenta suas contradições de maneira fragmentada. Aparecem como se os conflitos particulares não tivessem relação. Como se não

\footnotetext{
${ }^{11}$ Expressão que indica a produção de mercadoria com curto prazo de validade, tornando-a obsoleta mais rapidamente intencionalmente a fim de ampliar a circulação de mercadorias e realização do capital.
} 
houvesse relação entre a questão racial e a questão agrária, entre a questão de gênero e acumulação de capital; entre a diversidade e a questão ambiental; ou entre a saúde e a alimentação.

Por fim, o inventário das experiências de Educação Popular, a partir do pensamento de Paulo Freire, no contexto histórico, político e econômico, evidenciou que a educação popular, em seus fundamentos originários, tem visibilizado as contradições e às sutis mediações. Diante dessas constatações caberia indagar e ao mesmo tempo sugerir para futuras pesquisas, se: seria um desafio da educação popular contribuir na compreensão da totalidade da opressão? Sustentar o papel do sujeito histórico na recriação das relações sociais e com a natureza? Transgredir com esse ser coletivo - oprimidos, a dura coisificação do ser humano? Nos parecem que são inéditos viáveis, pois não podemos trespassar a vida planetária sem uma práxis transformadoras, pelo risco de incorrermos em uma postura coadjuvante dos rumos nefastos que a crise capitalista, em suas dimensões econômica, social, política, cultural, ambiental e educacional estão configurando.

\section{Referências}

Bardin, L, (2016). Análise de conteúdo. Edições 70.

Bogdan, R. C. e Biklen, S. K. (1994). Investigação qualitativa em educação. Uma introdução à teoria e aos métodos. (2a ed.), Porto Editora Ltda.

Brandão, C. R. (2002). Educação popular na escola cidadã. Vozes.

Coutinho, C. N. (1979). Democracia como valor Universal. In: Silveira, Ê., et all. Encontros com a Civilização Brasileira. Civilização Brasileira.

Fávero, O. (Org.) (1983). Cultura popular e Educação popular: memória dos anos 60. Edições Graal.

Fernandes, F. (1976). A Revolução Burguesa no Brasil. Ensaios de Interpretação Sociológica. (2a ed.), Zahar Editores: RJ.

Freire, P. (2011). Cartas a Guiné Bissau: registros de uma experiência em processo. (5a ed.), Paz e Terra.

Freire, P. (1979). Conscientização. Teoria e Prática da Libertação. Uma introdução ao pensamento de Paulo Freire. Cortez \& Moraes.

Freire, P. (1967). Educação como prática da Liberdade. Paz e Terra.

Freire, P. (2000). A educação na cidade. (4a ed.), Cortez.

Freire, P. (1989). Educadores de Rua. Uma abordagem crítica. Alternativas ao atendimento aos meninos de rua. N.1. Bogotá, Colômbia: UNICEF, Editorial Gente Nueva.

Freire, P. (1985) Extensão ou Comunicação. Coleção O Mundo Hoje. 24. (8a ed.), Paz e Terra.

Freire, P. (1978). Os Cristãos e a Libertação dos Oprimidos. Edições Base.

Freire, P. (1996). Pedagogia da Autonomia. Saberes necessários à prática educativa. Coleção Leitura. (30a ed.), Paz e Terra.

Freire, P. (1987). Pedagogia do Oprimido. (17a ed.), Paz e Terra.

Freire, P. (1993). Professora sim, tia não: cartas a quem ousa ensinar. Editora Olho D’Agua.

Gramsci, A. (1978). Concepção Dialética da História. Editora Civilização Brasileira.

Jara, O. (2020). A educação popular Latino-americana: história e fundamentos éticos, políticos e pedagógicos. Ação Educativa: CEAAL, ENFOC.

Katz, C. (2016). Neoliberalismo, neodesenvolvimentismo, socialismo. Expressão Popular.

Konder, L. (2002). A Questão da Ideologia. Companhia das Letras.

Lüdke, M. \& André, M. E.D.A. (1986). Pesquisa em educação: abordagens qualitativas. EPU.

Marx, K. \& Engels, F. ((2001). A ideologia alemã. Martins Fontes.

Mészáros, I. (2011). A crise estrutural do sistema do capital. In Para além do Capital: rumo a uma teoria da transição. Tradução Paulo Cesar Castanheira,: Boitempo.

Souza, A. I.. (2010). Paulo Freire: vida e obra. (2a ed.), Expressão Popular. 